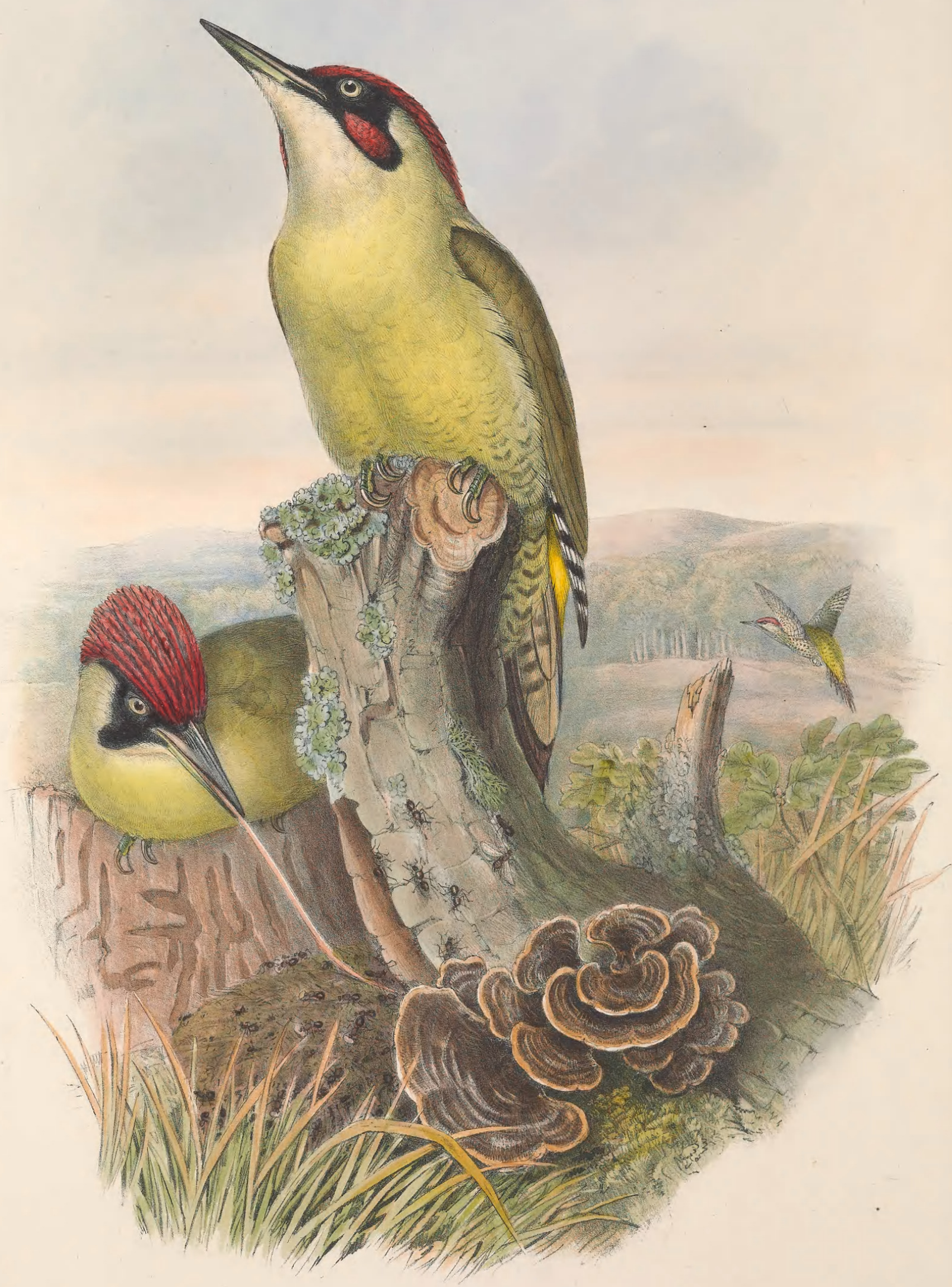




\title{
GECINUS VIRIDIS.
}

\author{
Green Woodpecker, or Yaffle.
}

Picus viridis et P. semirostris, Linn. Syst. Nat., tom. i. p. 175.

- alba et $P$. viridis, Nozem. Nederl. Vog., tom. iv. p. 373, pl. 190.

Gecinus viridis, Boie, Isis, 1828, p. 316.

frondium, G. pinetorum, et G. virescens, Brehm, Lehrb., p. 197.

Brachylophus viridis, Swains. Class. of Birds, vol. ii. p. 308.

Chloropicus viridis, Malh. Nouv. Class. des Picinées, Mém. Acad. Metz, 1848-1849, p. 351.

I know of no one of our indigenous birds which gives a more tropical character to the scenery than the Picus viridis, with its strongly contrasted colours of green, yellow, and scarlet; how desirable it is, then, that this fine bird should not be unnecessarily persecuted! When unmolested, it will not only inhabit our woods and fields, but will very frequently resort to our shrubberies, and trimly mown lawns, where its actions may be watched and studied from the window of the breakfast-room or the arbour in the garden; here it may be seen awkwardly leaping sideways over the grass, prying for ants and other insects, which it seeures by darting forth and retracting its long tongue with such amazing rapidity as to excite the astonishment of the observer. On leaving the grass-plat for the trees, it flies in a series of undulations, showing its bright yellow rump and scarlet crown to the utmost advantage. The terrestrial habits of the Green Woodpecker are quite in unison with its structure, which, particularly in the more feeble character of its legs and the less wedge-shaped form of its bill, differs from that of the Spotted Woodpeckers and the other members of the restricted genus Picus; it is also far less arboreal than they, mostly confining itself to fallen and decayed trees, pollard willows, and old wood fences. The ant-hill has far more attractions for it than the most beautiful tree; it is also said to be destructive to bees, and not to reject the fruits of the garden. Its loud, wild, laughing cry resounds through the woods, and may be heard far over the mead: this cry is so peculiar that, once heard, it can never be forgotten. In the spring the Green Woodpecker becomes very garrulous and noisy, and thus often betrays the site of its breeding-place, in a hole of some upright stately tree, to which it returns again and again for many years, unless it be displaced by the Starling, against which bird it is ever on the watch. The Duke of Argyll informs me that in Cliveden woods he has seen the Green Woodpecker sit motionless for hours together, at the entrance of its hole, to prevent its being occupied by a pair of Starlings which frequented the neighbourhood.

In England the Green Woodpecker is strictly an indigenous bird; for it remains with us all the year, and breeds in nearly every county. Mr. Rodd states that it is very common in the eastern woodlands of Cornwall, but that it is rare in the western, and almost unknown in the neighbourhood of Penzance. Macgillivray states that it "does not occur in any part of the northern or middle divisions of Scotland; and if it exist in the southern, it must be extremely rare." In Ireland it is unknown. M. Malherbe states that it inhabits the whole of the European continent, Persia, and Asia Minor.

"The Green Woodpecker," says Mr. Yarrell, " is generally seen either climbing over the bark of trees in search of its insect food or passing, by a short, somewhat laboured, and undulating flight, from one tree to another. When seen moving upon a tree, the bird is mostly ascending, in a direction more or less oblique, and is believed to be incapable of descending, unless this action be performed backwards. On flying to a tree to make a new search, it settles low down on the bole or body of the tree, but a few feet above the ground, generally below the lowest large branch, and proceeds from thence upwards, alternately tapping to induce any insect to change its place, pecking holes in a decayed branch that it may be able to reach any insects lodged within, or protruding its long extensible tongue to take up any insect on the surface; but, the summit of the tree once attained, the bird does not descend over the examined part, but flies off to another tree, or to another part of the same tree, to recommence its search lower down, and nearer the ground.

"The tongue and its appendages are admirably adapted to the bird's mode of life. Its great extensibility is obtained by the elongation of the two posterior branches or cornua of the bone of the tongue, which, extending round the back of the head and over the top, have the ends of both inserted together into the cavity of the right nostril. These elongations, forming a bow, are each accompanied throughout their length by a slender slip of muscle, by the contraction of which the bow is shortened, and the tongue pushed forward; another pair of muscles, folded twice round the upper part of the trachea, and from thence passing forward, are attached to the anterior part of the tongue, and by their contraction bring the tongue back again. The tongue itself is furnished at the tip with a horny point, and also with four or five bristle-like hairs on each side, which are directed backwards. At each side of the head, behind and below the external 
orifice of the ear, is a large and elongated parotid gland, from which a membranous duct passes as far forward as the point of union of the two bones forming together the lower mandible, on the inner surface of which the glutinous secretion of these large glands passes out, and may be seen to issue, on making slight pressure along the course of the glands. The flattened inner surface of the two bones, which are united along the distal part of their lower edge, forms the natural situation of the tongue when at rest within the mandibles; and every time it is drawn into the mouth, when the bird is feeding, it becomes covered with a fresh supply of the glutinous mucus. From a close examination of the stomachs of many specimens, I am induced to believe that the point of the tongue is not used as a spear, nor the food taken up by the beak, unless it be too heavy to be lifted by adhesion.

"Insects of various sorts, ants and their eggs, form the principal food; and I have seldom examined a recently-killed specimen the beak of which did not indicate, by the earth adhering to the base and to the feathers about the nostrils, that the bird had been at work at an ant-hill.

"The Green Woodpecker inhabits holes in trees, which it excavates or enlarges for its use, chiefly in the elm or the ash, in preference to those of harder wood. When excavating a hole in a tree for the purpose of incubation, the birds, it is said, will carry away the chips to a distance, in order that they may not lead to the discovery of their retreat, as other birds are known to carry away the egg-shells and the mutings of their young. It makes no nest, but deposits its eggs on the loose, soft fragments of the decayed wood. The eggs are from five to seven in number, smooth, shining, and pure white, 1 inch $2 \frac{1}{2}$ lines in length by $10 \frac{1}{4}$ lines in breadth. The young birds are fledged in June, and creep about the tree a short distance from the hole before they are able to fly. I have known the young birds to be taken from the tree and brought up by hand, becoming very tame, and giving utterance to a low note, not unlike that of a very young gosling. The adult birds also make a low jarring sound, which is supposed to be the call-note of sexes to each other. Their more common note is a loud sound which has been compared to a laugh, and they are said to be vociferous when rain is impending,- -hence their name of Rain-bird; and as it is highly probable that no change takes place in the weather without some previous alteration in the electrical condition of the atmosphere, we can easily understand that birds, entirely covered as they are with feathers, which are known to be readily affected by electricity, should be susceptible of certain impressions, which are indicated by particular actions: thus birds and other animals, covered only with the production of their highly sensible skin, become living barometers to good observers."

The male has the feathers of the base of the upper mandible, the lores, and a space surrounding the eye clothed with black feathers; crown and occipital feathers grey at the base, tipped with bright scarlet; from the base of the lower mandible a broad black moustache, in the centre of which is a brilliant patch of scarlet; neck, back, scapulars, wing-coverts, and wings olive-green, tinged with yellow ; rump sulphur-yellow; primaries greyish black, spotted with yellowish white sing the outer web and on the basal half of the inner web; secondaries and tertiaries green on the outer web, and greyish black spotted with dull white on the inner web; tail olive-black, indistinctly barred with dull yellowish white; sides of the head, throat, and under surface light yellowish grey; flanks greenish yellow, with zigzag markings of green on the thighs and also on the under tail-coverts ; irides creamy or pearl-white ; eyelash purplish blue ; upper mandible and tip of the lower mandible dull leaden black; the base of the lower mandible greenish yellow, fading into white near the gape; legs, toes, and claws olive-green.

The female is distinguished by having a smaller amount of scarlet on the head, and in the absence of the scarlet patch on the moustache.

In young birds the scarlet of the head is mingled with yellow and greyish black, the feathers changing from greyish white to yellow, and then to scarlet; similar changes take place in the scarlet of the moustache; the feathers of the upper surface are tipped with yellow; the under surface is streaked longitudinally on the neck, and transversely on the abdomen, with greyish black.

M. Malherbe, in his valuable 'Monograph of the Woodpeckers,' enumerates three or four varieties of this species which have come under his notice. These were chiefly remarkable for a deficiency in the usual colouring; but J. H. Gurney, Esq., has described, in the 'Zoologist' (p. 3800), a bird which had recently been presented to him, in which the feathers of the rump and upper tail-coverts were all margined and tipped with a beautiful flame-coloured red, instead of the usual edging of yellow; the feathers of the back were pointed with the beautiful golden-yellow edgings characteristic of the rump, and a similar colouring was observed on the ends of the feathers forming the three lower rows of the wing-coverts. In a subsequent page of the 'Zoologist' (4250), Robert Birkbeck, Esq., has mentioned that in the Museum at Pisa he saw three or four specimens similarly coloured; they were regarded as varieties of $P$. viridis.

The Plate represents the two sexes of the natural size, with a young bird in the distance. 


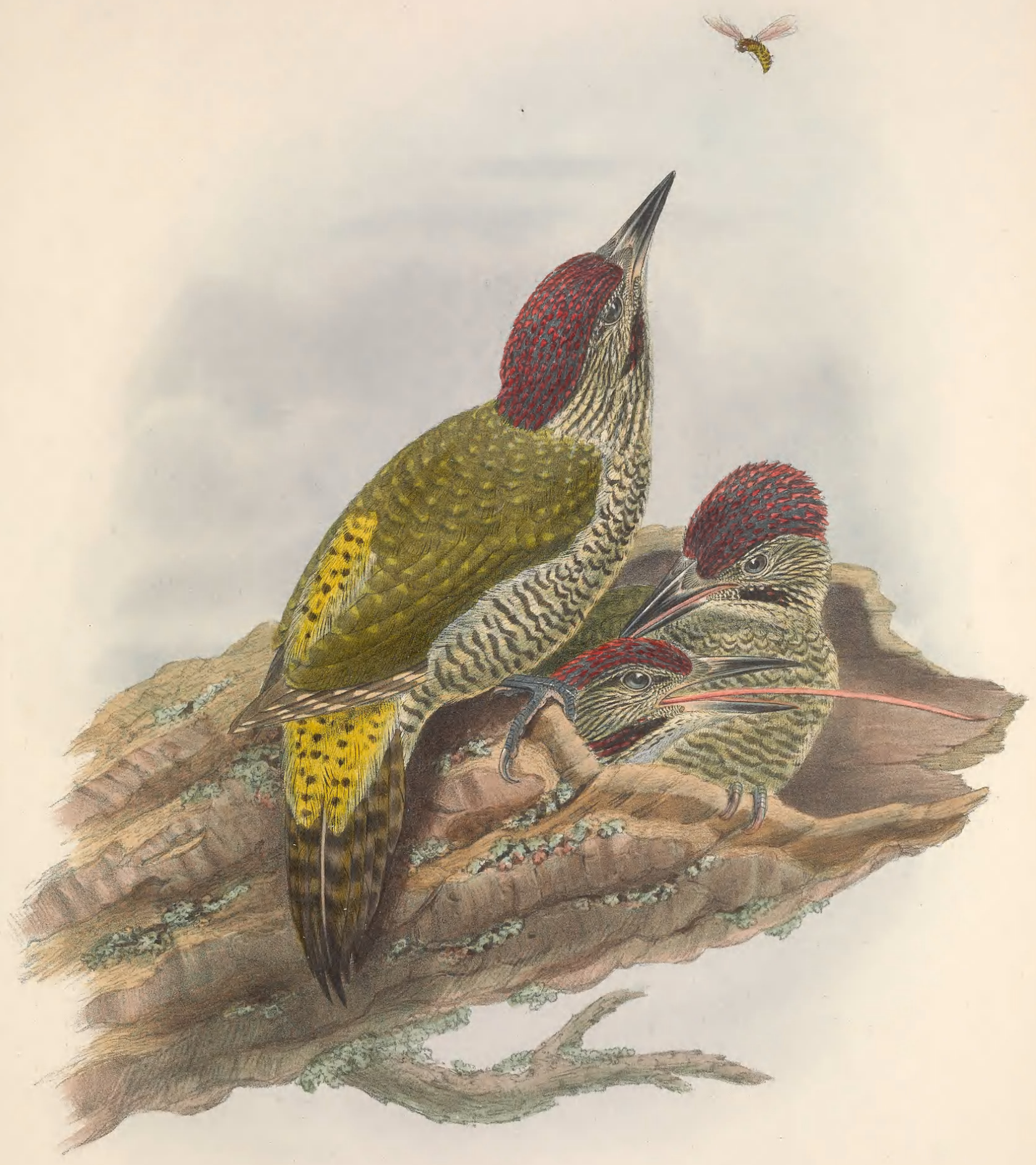




\section{$2 \mathrm{BHL}$ Biodiversity Heritage Library}

Gould, John. 1873. "Green Woodpecker or Yaffle, Gecinus viridis [PI. 74-75]." The birds of Great Britain 3, -. https://doi.org/10.5962/p.323960.

View This Item Online: https://www.biodiversitylibrary.org/item/221726

DOI: https://doi.org/10.5962/p.323960

Permalink: https://www.biodiversitylibrary.org/partpdf/323960

\section{Holding Institution}

Smithsonian Libraries

\section{Sponsored by}

Biodiversity Heritage Library

\section{Copyright \& Reuse}

Copyright Status: Public domain. The BHL considers that this work is no longer under copyright protection.

This document was created from content at the Biodiversity Heritage Library, the world's largest open access digital library for biodiversity literature and archives. Visit BHL at https://www.biodiversitylibrary.org. 